\title{
Design and Synthesis of 4-O-Podophyllotoxin Sulfamate Derivatives as Potential Cytotoxic Agents
}

\author{
Ammar Bader (D), ${ }^{1}$ Majdi M. Bkhaitan $\left(\mathbb{D},{ }^{1,2}\right.$ Ashraf N. Abdalla $(D),{ }^{1}$ \\ Qasem M. A. Abdallah $\mathbb{D}^{3,4}$ Hamed I. Ali $\mathbb{D}^{5},{ }^{5}$ Dima A. Sabbah $\mathbb{D}$, ${ }^{6}$ Ghadeer Albadawi $\mathbb{D}$, ${ }^{6}$ \\ and Ghassan M. Abushaikha $\mathbb{D}^{6}$
}

\author{
${ }^{1}$ Umm Al-Qura University, Makkah 21955, Saudi Arabia \\ ${ }^{2}$ Biomedical Sciences Unit, Arab American University, Jenin, State of Palestine \\ ${ }^{3}$ Department of Pharmacology and Toxicology, College of Pharmacy, Taif University, Taif, Saudi Arabia \\ ${ }^{4}$ Faculty of Pharmacy and Medical Sciences, University of Petra, Amman, Jordan \\ ${ }^{5}$ Rangel College of Pharmacy, Health Science Center, Texas A\&M University, Kingsville, TX 78363, USA \\ ${ }^{6}$ Department of Pharmacy, Al-Zaytoonah University of Jordan, P.O. Box 130, Amman 11733, Jordan
}

Correspondence should be addressed to Ammar Bader; ammarosio@yahoo.it

Received 13 November 2020; Revised 25 December 2020; Accepted 9 January 2021; Published 27 January 2021

Academic Editor: Akhilesh K. Tamrakar

Copyright (C) 2021 Ammar Bader et al. This is an open access article distributed under the Creative Commons Attribution License, which permits unrestricted use, distribution, and reproduction in any medium, provided the original work is properly cited.

\begin{abstract}
4-O-Podophyllotoxin sulfamate derivatives were prepared using the natural lignan podophyllotoxin. The prepared compounds were afforded by reacting $\mathrm{O}$-sulfonyl chloride podophyllotoxin with ammonia or aminoaryl/heteroaryl motif. Biological evaluation was performed in human breast cancer (MCF7), ovarian cancer (A2780), colon adenocarcinoma (HT29), and normal lung fibroblast (MRC5) cell lines. Compound $\mathbf{3}$ exhibited potent inhibitory activity and good selectivity margin. Compounds 2, 3, and $\mathbf{7}$ exerted apoptotic effect in MCF7 cells in a dose-dependent manner. The cytotoxicity of the verified compounds was inferior to that of podophyllotoxin.
\end{abstract}

\section{Introduction}

Podophyllotoxin 1 (PPT) is a natural lignan of the aryl tetralin class and the main component of Podophyllum peltatum L., and it was used in folk medicine since remote times $[1,2]$. It is generally considered as an effective anticancer agent with the ability to inhibit microtubules assembly by interacting with the tubulin proteins at the same binding site of colchicine, preventing the formation of the mitotic spindle $[3,4]$.<smiles>COc1cc([C@H]2c3cc4c(cc3[C@@H](O)[C@@H]3COC(=O)[C@H]23)OCO4)cc(OC)c1OC</smiles>

Podophyllotoxin 1 


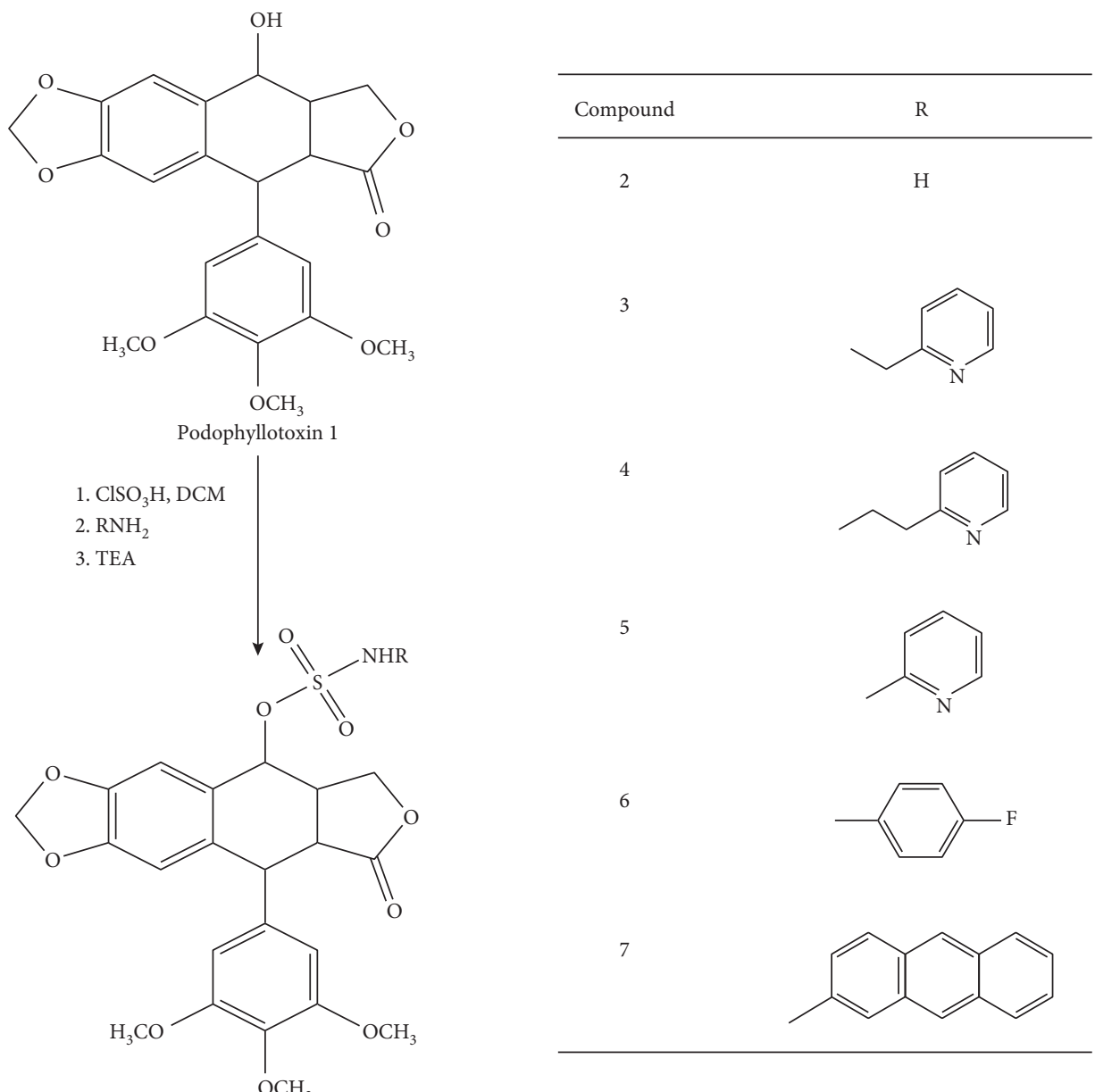

Compounds 2-7

Scheme 1: Synthesis of compounds 2-7.

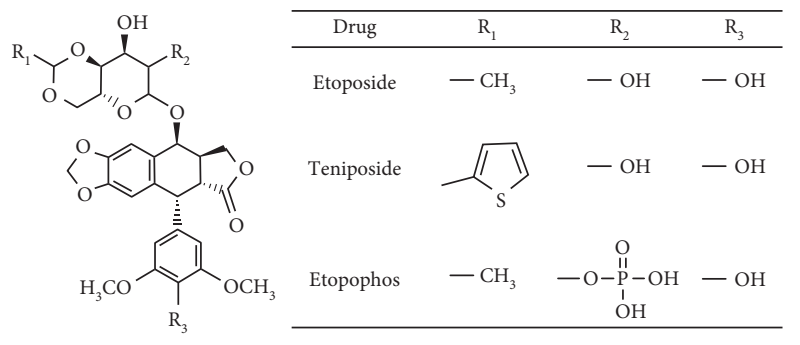

FIgURe 1: Podophyllotoxin derivatives in clinical use.

Serious adverse effects, including nausea, vomiting, diarrhea, abdominal pain, thrombocytopenia, leucopenia, cytotoxicity, and lack of oocytes maturation, were documented for PPT [5-7]. In addition, PPT suffers from poor water solubility and poor pharmacokinetic properties, limiting its wide spread in clinical use [8]. Nevertheless, due to its extraordinary biological activity and longtime use in traditional medicine, PPT and $4^{\prime}$-demethylpodophyllotoxin will continue to represent an important lead in the development of new active entities [9-13].

Multiple structural modifications were made on podophyllotoxin structure to improve the potency and pharmacokinetic properties as well as to overcome drug resistance. In particular, the C-4 position has represented a primary target for these modifications $[8,11]$. As a matter of a fact, multiple in vitro and in silico studies have demonstrated that C-4 molecular area is suitable to lodge significant structural varieties $[10,14]$. These efforts were crowned by the preparation and introduction of potent derivatives such as the highly prescribed anticancer drugs etoposide, teniposide, and the prodrug etopophos (Figure 1) [15].

It is worth mentioning that the cytotoxic mechanism of these derivatives is linked to their inhibition of topoisomerase II (topo II), inducing cell death, by enhancing the topo II-mediated DNA cleavage through the stabilization of the transitory DNA/topo II cleavage complex [16]. These agents including etoposide were associated with numerous limitations such as cytotoxicity toward normal cells, drug resistance, and poor bioavailability $[17,18]$.

Recently, the design of 4-substituted podophyllotoxin derivatives containing sulfonamide groups was reported [19]. This study exploited the diverse physical, chemical, and biological properties of reported derivatives, in particular, compound (A) in Figure 2; an $\mathrm{N}$-(aminosulfonyl)-4-podophyllotoxin carbamate derivative demonstrated high in vitro 


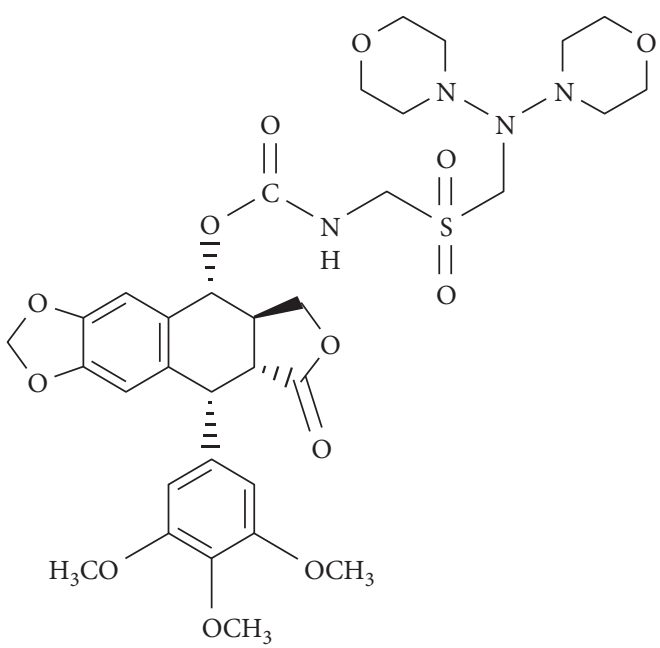

(a)

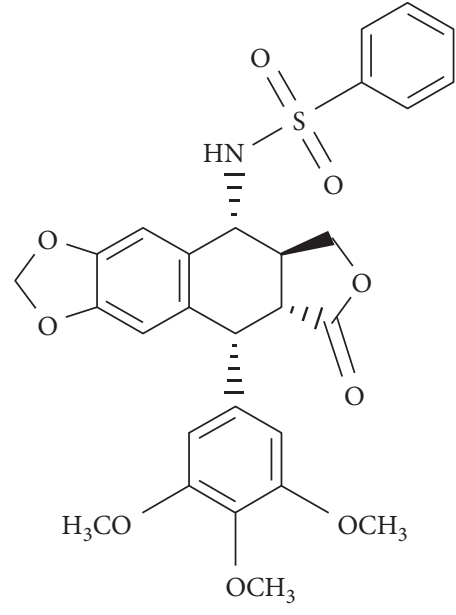

(b)

FIgURE 2: (a) $\mathrm{N}$-(aminosulfonyl)-4-podophyllotoxin carbamate derivative; (b) 4-sulphonamide derivatives.

antiproliferative activity against tumor cell lines such as cervix carcinoma (HeLa), lung carcinoma (A-549), ileocecal carcinoma (HCT-8), and liver carcinoma (HepG2) cell lines, whereas low toxicity against the normal lung (WI-38) cell line. Biological data showed that the derivatives inhibit tubulin polymerization and microtubule assembly in HeLa cells [19]. In another study, 4-sulfonylamino derivatives exemplified by compound B in Figure 2 exerted highly potent cytotoxicity against human prostate (DU145), colon (HT29), breast (MCF7), multidrug-resistant breast (MCF7/ADR), lung (NCI-H460), and brain (U251) cancer cell lines [20]. In addition, a novel series of C- $4 \beta$-disulfide/trisulfide-containing podophyllotoxin derivatives showed good anticancer activity against oral cancer (KB/VCR) cell lines superior to that of etoposide [21]. This work reports the design and synthesis of 4-O-podophyllotoxin sulfamate derivatives having various substituents to afford more potent and less toxic compounds.

\section{Materials and Methods}

2.1. Chemicals. All chemicals, reagents, and solvents were of analytical grade and used directly without extra purification. Chloroform, methanol, cyclohexane, ethylacetate, dichloromethane (DCM), and triethylamine (TEA) were purchased from Fisher Scientific (UK) and Tedia Company (USA). Podophyllotoxin, chlorosulfonic acid, ammonia, 2picolylamine(2-aminomethyl pyridine), 2-(2-aminoethyl) pyridine, 2-amino pyridine, 4 -fluoroaniline, and 2 -amino anthracene were purchased from Sigma-Aldrich (Germany).

2.2. Instruments. Nuclear Magnetic Resonance (NMR) charts were recorded by BRUKER $500 \mathrm{MHz}$ Avance III. Chemical shifts are reported in ppm related to tetramethylsilane (TMS), internal standard. Deuterated chloroform $\left(\mathrm{CDCl}_{3}\right)$ was used as a solvent in sample preparation. ${ }^{1} \mathrm{H}-\mathrm{NMR}$ data are reported as following: chemical shift (ppm), multiplicity, coupling constant $(\mathrm{Hz})$, number of protons, and their corresponding proton(s). For initial identification of compounds, infrared (IR) spectra were recorded using Shimadzu 8400 FT-IR spectrophotometer (Japan). All tested compounds were triturated with potassium bromide (KBr) and compressed into thin film discs (ACros, Belgium). The melting point (m.p) was measured using Gallenkamp melting point apparatus (Gallenkamp, UK). Thin layer chromatography (TLC) was performed on $20 \times 20 \mathrm{~cm}$ aluminum plates precoated fluorescent silica gel GF254 (ALBET, Germany). The TLC was visualized under UV lamp, Spectroline ${ }^{\circledR}$ cabinet, Model CX-20 (USA), at 254 and/or $360 \mathrm{~nm}$. For the efficient and gentle removal of solvents from the samples, Rotavapor model R-114 (Buchi, Switzerland) was used.

\subsection{Synthesis}

2.3.1. General Procedure for the Synthesis of Compounds 2-7. To a stirred solution of $\mathbf{1}(1.0 \mathrm{mmol})$ in dry dichloromethane $\left(\mathrm{CH}_{2} \mathrm{Cl}_{2}\right)(10 \mathrm{~mL})$ cooled in ice bath, chlorosulfonic acid $\left(\mathrm{ClSO}_{3} \mathrm{H}\right)(1.5 \mathrm{mmol})$ solution in dry $\mathrm{CH}_{2} \mathrm{Cl}_{2}(10 \mathrm{~mL})$ was added cautiously drop wise. After stirring for $1 \mathrm{~h}$ at room temperature, ammonia or aryl amines $(2.0 \mathrm{mmol})$ were added. The mixture was reacted for $1-4 \mathrm{~h}$ at room temperature. Then, triethylamine (TEA) $(3.0 \mathrm{mmol})$ was added and filtered. The filtrate was evaporated to dryness, and the crude residue was purified by column chromatography on silica gel with cyclohexane-ethylacetate to afford compounds 2-7, Scheme 1.

2.3.2. 4-O-Podophyllotoxin Sulfamate (2). White powder (44\%); m.p $234^{\circ} \mathrm{C} ; R_{f}=0.7$ in (chloroform: methanol, $98: 2$ ); ${ }^{1} \mathrm{H}-\mathrm{NMR}\left(400 \mathrm{~Hz}, \mathrm{CDCl}_{3}\right): \delta=3.23(\mathrm{~m}, 1 \mathrm{H}), 3.74(\mathrm{~s}, 6 \mathrm{H}$, $\left.2 \mathrm{xOCH}_{3}\right), 3.80\left(\mathrm{~s}, 3 \mathrm{H}, \mathrm{OCH}_{3}\right), 4.60(\mathrm{~m}, 1 \mathrm{H}), 5.70(\mathrm{~m} .1 \mathrm{H})$, $4.77(\mathrm{~d}, J=5.20 \mathrm{~Hz}, 1 \mathrm{H}), 5.95$ (br $\left.s, 2 \mathrm{H}, \mathrm{NH}_{2}\right), 6.20$ (d, $J=7.20 \mathrm{~Hz}, 2 \mathrm{H}$ ), 6.35 (s, 2H, methylenedioxy), $6.50(\mathrm{~s}, 1 \mathrm{H}$, $\mathrm{Ar}-\mathrm{H}), 7.17$ (s, $2 \mathrm{H}, \mathrm{Ar}-\mathrm{H}), 7.32(\mathrm{~s}, 1 \mathrm{H}, \mathrm{Ar}-\mathrm{H}) \mathrm{ppm} ;{ }^{13} \mathrm{C}-$ NMR $\left(\mathrm{CDCl}_{3}\right): \delta=29.7(1 \mathrm{C}), 45.0(1 \mathrm{C}), 46.5(1 \mathrm{C}), 50.6(1 \mathrm{C})$, 56.0 (1C), 56.3 (2C), 60.9 (1C), 62.2 (1C), 101.2 (1C), 106.1 (2C), $106.6(1 \mathrm{C}), 112.0(1 \mathrm{C}), 128,8$ (1C), 134.5 (1C), 140.0 
(1C), 146.1 (1C), 147.6 (1C), 150.1 (1C), 153.3 (1C), 178.4 (1C) ppm; IR ( $\mathrm{KBr}$ disc): $v=3350\left(\mathrm{NH}_{2}\right.$ sulfamate), 1730 (CO-g-lactone), $1600\left(\mathrm{OSO}_{2}\right), 1430\left(\mathrm{OSO}_{2}\right) \mathrm{cm}^{-1}$.

2.3.3. 4-N-(2-Pyridinylmethyl)podophyllotoxin Sulfamate (3). White powder (31\%); m.p $230^{\circ} \mathrm{C} ; R_{f}=0.75$ in (chloroform: methanol, 98:2); ${ }^{1} \mathrm{H}-\mathrm{NMR}\left(400 \mathrm{~Hz}, \mathrm{CDCl}_{3}\right): \delta=3.0(\mathrm{~s}, 2 \mathrm{H})$, $3.15(\mathrm{~m}, 1 \mathrm{H}), 3.74\left(\mathrm{~s}, 6 \mathrm{H}, 2 \mathrm{xOCH}_{3}\right), 3.80\left(\mathrm{~s}, 3 \mathrm{H}, \mathrm{OCH}_{3}\right), 4.60$ $(\mathrm{m}, 1 \mathrm{H}), 5.55(\mathrm{~m}, 1 \mathrm{H}), 4.77(\mathrm{~d}, J=5.18 \mathrm{~Hz}, 1 \mathrm{H}), 5.75$ (br $s, 1 \mathrm{H}$, $\mathrm{NH}), 6,15$ (m, 1H), 6.20 (d, J=7.15 Hz, 2H), $6.25(\mathrm{~m}, 1 \mathrm{H}), 6.35$ (s, 2H, methylenedioxy), $6.50(\mathrm{~s}, 1 \mathrm{H}, \mathrm{Ar}-\mathrm{H}), 7.07(\mathrm{~s}, 2 \mathrm{H}$, Ar-H), 7.15 (s, 1H, Ar-H), 7.40 (m, 1H), 7, 45 (m, 1H) ppm; ${ }^{13} \mathrm{C}-\mathrm{NMR}\left(\mathrm{CDCl}_{3}\right): \delta=24(1 \mathrm{C}), 29.7(1 \mathrm{C}), 45.0(1 \mathrm{C}), 46.5(1 \mathrm{C})$, 50.6 (1C), 56.2 (1C), 57.9 (2C), 60.9 (1C), 67.4 (1C), 101.5 (1C), 108.3 (2C), 109.6 (1C), 111.0 (1C), 128,8 (1C), 134.5 (1C), 137.2 (1C), 140.0 (1C), 143.6 (1C), 146.1 (1C), 147.6 (1C), 148.2 (1C), 150.1 (1C), 152.5 (1C), 153, 1 (1C), 154.0 (1C), 175.0 (1C) ppm; IR (KBr disc): $\nu=3310$ ( $\mathrm{NH}_{2}$ sulfamate), 1710 (CO-g-lactone), $1570\left(\mathrm{OSO}_{2}\right), 1410\left(\mathrm{OSO}_{2}\right) \mathrm{cm}^{-1}$.

2.3.4. 4-N-(2-Pyridinylethyl)podophyllotoxin Sulfamate (4). White powder $(20 \%)$; m.p $225^{\circ} \mathrm{C} ; R_{f}=0.8$ in (chloroform: methanol, $\left.98: 2) ;{ }^{1} \mathrm{H}-\mathrm{NMR}\left(400 \mathrm{~Hz}, \mathrm{CDCl}_{3}\right)\right): \delta=2.05(\mathrm{~m}, 2 \mathrm{H})$, $2.78(\mathrm{~m}, 2 \mathrm{H}), 3.05(\mathrm{~m}, 1 \mathrm{H}), 3.74\left(\mathrm{~s}, 6 \mathrm{H}, 2 \mathrm{xOCH}_{3}\right), 3.80(\mathrm{~s}, 3 \mathrm{H}$, $\left.\mathrm{OCH}_{3}\right), 4.50(\mathrm{~m}, 1 \mathrm{H}), 5.25(\mathrm{~m} .1 \mathrm{H}), 4.77(\mathrm{~m}, 1 \mathrm{H}), 5.75(\mathrm{br} s, 1 \mathrm{H}$, $\mathrm{NH}), 6,10(\mathrm{~m}, 1 \mathrm{H}), 6.15(\mathrm{~m}, 2 \mathrm{H}), 6.17(\mathrm{~m}, 1 \mathrm{H}), 6.30(\mathrm{~s}, 2 \mathrm{H}$, methylenedioxy), 6.41 (s, 1H, Ar-H), 6.90 (s, 2H, Ar-H), 7.0 (s, $1 \mathrm{H}, \mathrm{Ar}-\mathrm{H}), 7.23(\mathrm{~m}, 1 \mathrm{H}), 7,30(\mathrm{~m}, 1 \mathrm{H}) \mathrm{ppm} ;{ }^{13} \mathrm{C}-\mathrm{NMR}$ $\left(\mathrm{CDCl}_{3}\right): \delta=14.1(1 \mathrm{C}), 22.7(1 \mathrm{C}), 29.2(1 \mathrm{C}), 42.8(1 \mathrm{C}), 46.1(1 \mathrm{C})$, 50.3 (1C), 56.2 (1C), 56.3 (2C), 60.8 (1C), $67.1(1 \mathrm{C}), 101.3(1 \mathrm{C})$, 107.7 (2C), 109.6 (1C), 111.0 (1C), 128.8 (1C), 134.5 (1C), 137.2 (1C), 140.0 (1C), 143.6 (1C), 146.1 (1C), 147.3 (1C), 148.0 (1C), 150.1 (1C), 152.3 (1C), 153.0 (1C), 153.2 (1C), 167.0 (1C) ppm; IR (KBr disc): $v=3300\left(\mathrm{NH}_{2}\right.$ sulfamate), 1700 (CO-g-lactone), $1566\left(\mathrm{OSO}_{2}\right), 1410\left(\mathrm{OSO}_{2}\right) \mathrm{cm}^{-1}$

2.3.5. 4-N-(2-Pyridinyl)podophyllotoxin Sulfamate (5). White powder (35\%); m.p $230^{\circ} \mathrm{C}$ decomp.; $R_{f}=0.73$ in (chloroform: methanol, 98:2); ${ }^{1} \mathrm{H}-\mathrm{NMR}\left(400 \mathrm{~Hz}, \mathrm{CDCl}_{3}\right): \delta=3.32$ $(\mathrm{m}, 1 \mathrm{H}), 3.80\left(\mathrm{~s}, 6 \mathrm{H}, 2 \mathrm{xOCH}_{3}\right), 3.85\left(\mathrm{~s}, 3 \mathrm{H}, \mathrm{OCH}_{3}\right), 4.70(\mathrm{~m}$, 1H), 5.95 (m.1H), 4.77 (m, 1H), 6.55 (br s, 1H, NH), 6.27 (m, $1 \mathrm{H}), 6.32(\mathrm{~m}, 2 \mathrm{H}), 6.35(\mathrm{~m}, 1 \mathrm{H}), 6.43$ (s, 2H, methylenedioxy), 6.65 (s, 1H, Ar-H), 7.20 (s, 2H, Ar-H), 7.30 (s, 1H, Ar-H), 7.64 $(\mathrm{m}, 1 \mathrm{H}), 7,75(\mathrm{~m}, 1 \mathrm{H}) \mathrm{ppm} ;{ }^{13} \mathrm{C}-\mathrm{NMR}\left(\mathrm{CDCl}_{3}\right): \delta=31(1 \mathrm{C})$, 45.5 (1C), 46.9 (1C), 52 (1C), 57 (1C), 58.7 (2C), 63 (1C), 68.2 (1C), 101.7 (1C), 108.8 (2C), 110.7 (1C), 112.0 (1C), 129.4 (1C), 134.9 (1C), 137.7 (1C), 140.6 (1C), 144.4 (1C), 147 (1C), 148.3 (1C), 149 (1C), 150.4 (1C), 153.3 (1C), 154 (1C), 154.7 (1C), 177.2 (1C) ppm; IR (KBr disc): $v=3390\left(\mathrm{NH}_{2}\right.$ sulfamate), 1730 (CO-glactone), $1620\left(\mathrm{OSO}_{2}\right), 1460\left(\mathrm{OSO}_{2}\right) \mathrm{cm}^{-1}$.

2.3.6. 4-N-(4-Flourophenyl)podophyllotoxin Sulfamate (6). White powder $(20 \%)$; m.p $220^{\circ} \mathrm{C} ; R_{f}=0.8$ in (chloroform: methanol, $98: 2) ;{ }^{1} \mathrm{H}-\mathrm{NMR}\left(400 \mathrm{~Hz}, \mathrm{CDCl}_{3}\right): \delta=3.0(\mathrm{~m}, 1 \mathrm{H})$, $3.76\left(\mathrm{~s}, 6 \mathrm{H}, 2 \mathrm{xOCH}_{3}\right), 3.82\left(\mathrm{~s}, 3 \mathrm{H}, \mathrm{OCH}_{3}\right), 4.64(\mathrm{~m}, 1 \mathrm{H}), 5.62$ (m.1H), $4.74(\mathrm{~m}, 1 \mathrm{H}), 5.95$ (br $s, 1 \mathrm{H}, \mathrm{NH}), 6.30(\mathrm{~m}, 1 \mathrm{H}), 6.27$ $(\mathrm{d}, J=5.30 \mathrm{~Hz}, 2 \mathrm{H}), 6.32(\mathrm{~d}, J=6.10 \mathrm{~Hz}, 2 \mathrm{H}, \mathrm{Ar}-\mathrm{H}), 6.40$ (s, $2 \mathrm{H}$, methylenedioxy), 6.55 (d, $J=6.15 \mathrm{~Hz}, 2 \mathrm{H}, \mathrm{Ar}-\mathrm{H}), 7.10$ (s, 2H, Ar-H), 7.21 (s, 1H, Ar-H) ppm; ${ }^{13} \mathrm{C}-\mathrm{NMR}\left(\mathrm{CDCl}_{3}\right)$ : $\delta=30.7$ (1C), 45.4 (1C), 46.8 (1C), 51 (1C), 56.6 (1C), 58.3 (2C), 61.2 (1C), 67.8 (1C), 102.3 (1C), 108.6 (2C), 109.9 (1C), 111.3 (1C), 129.2 (1C), 134.8 (1C), 137.6 (1C), 140.9 (1C), 144 (1C), 146.5 (1C), 148.2 (1C), 148.7 (1C), 150.1 (1C), 152.7 (1C), 153.4 (1C), 154.3 (1C), 156.7 (1C), 176.0 (1C) ppm; IR (KBr disc): $\nu=3330$ ( $\mathrm{NH}_{2}$ sulfamate), 1710 (CO-g-lactone), $1570\left(\mathrm{OSO}_{2}\right), 1430\left(\mathrm{OSO}_{2}\right) \mathrm{cm}^{-1}$. This compound was unstable, and it was excluded from the biological assay.

2.3.7. 4-N-(2-Anthracenyl)podophyllotoxin Sulfamate (7). White powder (58\%); m.p $246^{\circ} \mathrm{C}$ decomp.; $R_{f}=0.89$ in (chloroform: methanol, 98:2); ${ }^{1} \mathrm{H}-\mathrm{NMR}\left(400 \mathrm{~Hz} \mathrm{CDCl}_{3}\right)$ ): $\delta=3.08(\mathrm{~m}, 1 \mathrm{H}), 3.77\left(\mathrm{~s}, 6 \mathrm{H}, 2 \mathrm{xOCH}_{3}\right), 3.81\left(\mathrm{~s}, 3 \mathrm{H}, \mathrm{OCH}_{3}\right)$, $4.64(\mathrm{~m}, 1 \mathrm{H}), 4.89(\mathrm{~m} .1 \mathrm{H}), 3.81(\mathrm{~m}, 1 \mathrm{H}), 5.96(\mathrm{br} s, 1 \mathrm{H}, \mathrm{NH})$, $4.64(\mathrm{~m}, 2 \mathrm{H}), 6.25(\mathrm{~m}, 1 \mathrm{H}, \mathrm{Ar}-\mathrm{H}), 6.35$ (s, 2H, methylenedioxy), $6.55(\mathrm{~s}, 1 \mathrm{H}), 6.83(\mathrm{~m}, 2 \mathrm{H}, \mathrm{Ar}-\mathrm{H}), 7.09(\mathrm{~s}, 1 \mathrm{H})$, $7.43(\mathrm{~m}, 1 \mathrm{H}), 7.52(\mathrm{~m}, 2 \mathrm{H}), 7.82(\mathrm{~m}, 1 \mathrm{H}), 7.91(\mathrm{~m}, 2 \mathrm{H}), 8.11$ (s, $1 \mathrm{H}, \mathrm{Ar}-\mathrm{H}), 8.26$ (s, 1H, Ar-H) ppm; ${ }^{13} \mathrm{C}-\mathrm{NMR}\left(\mathrm{CDCl}_{3}\right)$ : $\delta=29.7$ (1C), 45.9 (1C), 46.2 (1C), 50.3 (1C), 56.3 (1C), 58.0 (2C), 60.8 (1C), 69.0 (1C), 101.6 (1C), $108.4(2 \mathrm{C}), 109.6$ (1C), 110.8 (1C), 105.6 (1C), 120.9 (1C), 121 (1C), 123 (1C), 125.1 (1C), 125.8 (1C), 126, 5 (1C), 127 (1C), $128.4(1 \mathrm{C}), 128.9$ (1C), 129.2 (1C), 131.9 (1C), 133.6 (1C), 134.8 (1C), 137.6 (1C), 146.5 (1C), 148.2 (1C), 148.7 (1C), 150.1 (1C), 152.4 (1C), 152.9 (1C), 171.0 (1C) ppm; IR (KBr disc): $v=3310\left(\mathrm{NH}_{2}\right.$ sulfamate), 1680 (CO-g-lactone), $1575 \quad\left(\mathrm{OSO}_{2}\right), 1410$ $\left(\mathrm{OSO}_{2}\right) \mathrm{cm}^{-1}$.

2.4. Cell Culture. Three cancer cell lines, human breast adenocarcinoma (MCF7), human ovary adenocarcinoma (A2780), and human colon adenocarcinoma (HT29), in addition the normal human fetal lung fibroblast (MRC5), were used. All cell lines were obtained from the ATCC. The three cancer cells were subcultured in RPMI-1640 media (10\% FBS), while MRC5 was maintained in Eagles minimum essential medium (EMEM, $10 \% \mathrm{FBS}$ ), all at $37^{\circ} \mathrm{C}, 5 \% \mathrm{CO}_{2}$, and $100 \%$ relative humidity [22].

2.5. Cytotoxicity Assay. As previously reported [23, 24], the cytotoxicity of the six compounds, including podophyllotoxin as reference, was evaluated by the MTT assay. The three cell lines and one normal fibroblast cells were separately cultured in 96-well $\left(3 \times 10^{3} /\right.$ well $)$ and incubated at $37^{\circ} \mathrm{C}$ overnight. Final compound concentrations are as follows: 0 , $0.005,0.050,0.500,5.000$, and $25.000 \mu \mathrm{M}$ (DMSO 0.1\%; $n=3)$. Plates were incubated for $72 \mathrm{~h}$, followed by addition of MTT to each well. Plates were incubated for $3 \mathrm{hr}$, supernatant was aspirated, and DMSO was added to each well. The absorbance was read on multiplate reader. The optical density of the purple formazan $\mathrm{A}_{550}$ is proportional to the number of viable cells. Compound concentration causing $50 \%$ inhibition $\left(\mathrm{IC}_{50}\right)$ compared to control cell growth (100\%) was determined. GraphPad Prism version 5.00 for 
TABLe 1: Cytotoxic activity of the verified compounds $(2,3,4,5$, and 7) (MTT $72 \mathrm{~h}, \mathrm{IC} 50 \pm \mathrm{SD} \mu \mathrm{M})$.

\begin{tabular}{lcccc}
\hline Compound & MCF7 & A2780 & HT29 & MRC5 \\
\hline 2 & $0.648 \pm 0.087$ & $0.729 \pm 0.363$ & $1.343 \pm 0.637$ & $7.507 \pm 1.510$ \\
3 & $0.150 \pm 0.060^{*}$ & $0.179 \pm 0.010^{*}$ & $0.222 \pm 0.098^{*}$ & $2.027 \pm 0.250$ \\
4 & $0.212 \pm 0.010^{*}$ & $0.456 \pm 0.180^{*}$ & $0.228 \pm 0.075^{*}$ & $0.048 \pm 0.003^{* *}$ \\
5 & $0.184 \pm 0.052^{*}$ & $0.132 \pm 0.012^{*}$ & $1.048 \pm 0.005$ & $0.047 \pm 0.042^{* *}$ \\
7 & $2.120 \pm 0.989$ & $3.652 \pm 1.939$ & $5.082 \pm 0.673$ & $9.076 \pm 1.010$ \\
Podophyllotoxin & $0.004 \pm 0.001^{* * *}$ & $0.007 \pm 0.001^{* * *}$ & $0.002 \pm 0.001^{* * *}$ & $0.043 \pm 0.060^{* *}$ \\
\hline
\end{tabular}

Data are representation of three independent experiments $(n=4)$. Statistical difference (one-way ANOVA, Tukey's post hoc): $p<0.05^{*}, p<0.01^{* *}$, and $p<0.001^{* * *}$ were considered significant.
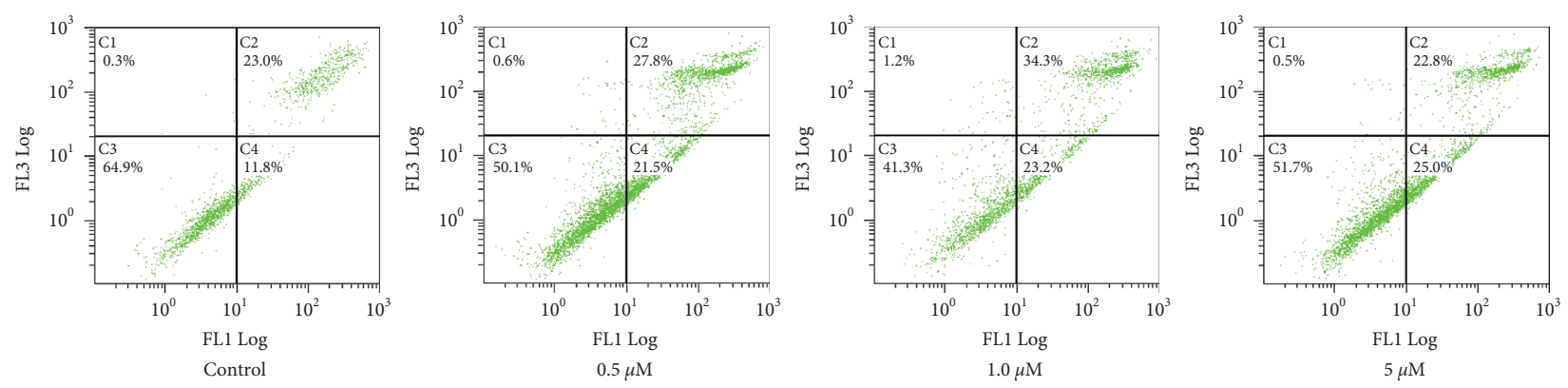

(a)
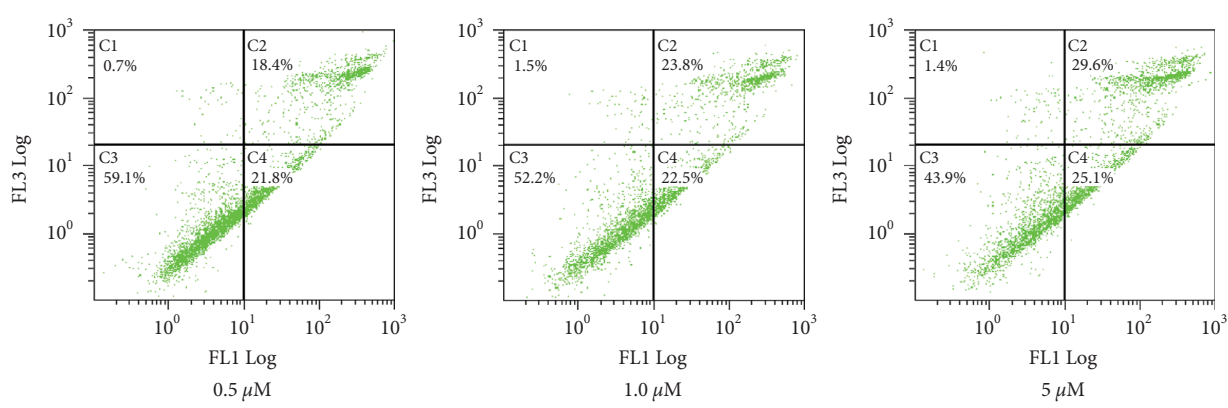

(b)
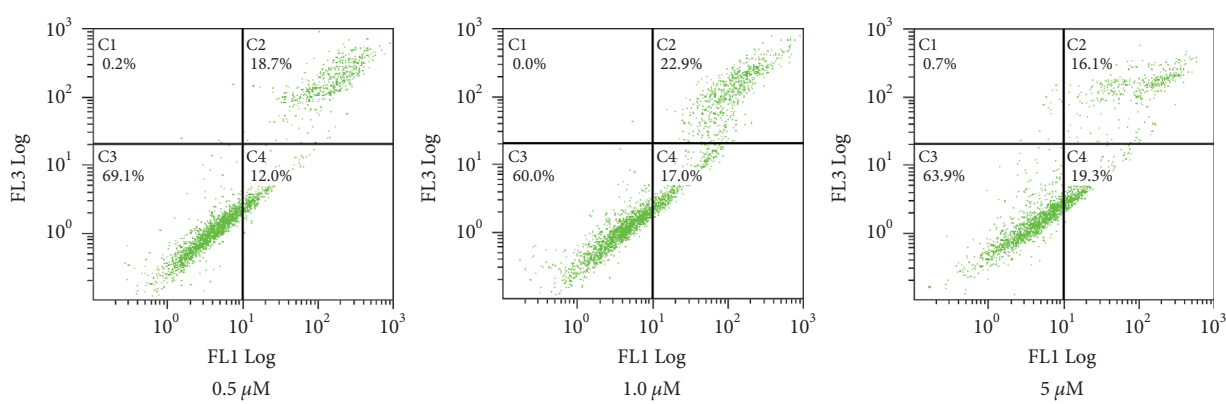

(c)

FIGURE 3: Histogram showing different phases of staining MCF7 cells with annexin V FITC/PI treated with vehicle control. Compounds (a) 2, (b) 3, and (c) 7, each in three concentrations, $24 \mathrm{~h}$. $X$-axis: annexin (V); $y$-axis: PI. C1: (necrosis death, PI+/annexin V-); C2: (late apoptosis, PI+/annexin V+); C3: (living cells, PI-/annexin V-); C4: (early apoptosis, PI-/annexin V+). Experiment was repeated 2x.

Windows, GraphPad Software, San Diego California, USA, was used for analysis.

2.6. Annexin V FITC/PI Apoptosis Assay. Annexin V FITC/ PI assay was used to evaluate possible ability to induce apoptosis [25]. MCF7 cells were cultured in 6 well plates $\left(1 \times 10^{5}\right.$ cells/well $)$ overnight at $37^{\circ} \mathrm{C}$. Compounds 2,3 , and 7 were used to treat cells $(0,0.5,1.0$, and $5.0 \mu \mathrm{M})$. After $24 \mathrm{~h}$, the supernatant of treated cells was collected in tubes and kept in ice, and cells were trypsinized and incubated at $37^{\circ} \mathrm{C}$ before being added to the tubes. MCF7 cells were centrifuged $(2000 \mathrm{rpm})$ and washed with PBS (x1), and pellets resuspended in the binding buffer $(100 \mu \mathrm{L})$ and annexin V FITC 
$(10 \mu \mathrm{L})$. Tubes were incubated at room temperature in dark for $20 \mathrm{~min}$, before adding binding buffer $(400 \mu \mathrm{L})$ and $10 \mu \mathrm{L}$ propidium iodide (PI). Analysis was performed by flow cytometry (BC, FC500, USA). Different cell populations (early apoptotic, late apoptotic, and necrotic cells) were identified by annexin $\mathrm{V}$ and PI staining.

\section{Results and Discussion}

3.1. Chemistry. The synthesis of podophyllotoxin sulfamates, compounds 2-7, was achieved by reaction of podophyllotoxin (1) with chlorosulfonic acid in dry dichloromethane (DCM) (Scheme 1). Then, the podophyllotoxin sulfonyl chloride intermediate derivatives were immediately treated with ammonia or with the corresponding aryl and heteroaryl amines in the presence of triethylamine (TEA). The structures of the target compounds $2-7$ were identified by IR, ${ }^{1} \mathrm{H}-\mathrm{NMR}$, and ${ }^{13} \mathrm{C}$ NMR spectral analysis.

3.2. Cytotoxicity Assay. The cytotoxicity of the new podophyllotoxin derivatives against breast, ovarian, and colon cancer cells was evaluated using MTT assay. Additionally, one normal cell line was tested to assess the selectivity of the new derivatives. Compound 3 shows the highest activity against the three cell lines $(0.150-0.220 \mu \mathrm{M})$, and it was 9.1-13.5-fold more selective against MCF7, A2780, and HT29 compared to MRC5 cells. Compound 2 also showed $\leq 1 \mu \mathrm{M}$ activity against MCF7, A2780, and HT29, and it was less cytotoxic against MRC5 cells. Compounds $\mathbf{4}$ and $\mathbf{5}$ showed similar activity to 3 , but they showed no selectivity against MRC5. Finally, compound 7 was the least active $\left(\mathrm{IC}_{50}: 2.120-5.082 \mu \mathrm{M}\right)$, but it showed 2-4-fold selectivity against the normal cells. Compound 3 showed the comparable activity to podophyllotoxin (Table 1).

3.3. Annexin V FITC/PI Apoptosis Assay. Compounds 2, 3, and 7 were selected for further investigations to explain their mechanism of action. Annexin V FITC/PI assay was used to evaluate whether they can induce apoptosis or not in MCF7 cells, following $24 \mathrm{~h}$ treatment. Compounds 2, 3, and 7 increased the early apoptotic MCF7 cell populations in a dose-dependent manner (1.7-2.2-fold, compared to control), as shown in Figure 3.

The desired podophyllotoxin sulfamate derivatives were successfully prepared in a one-pot reaction in good yields. This novel method was developed in our lab applying the coupling reaction between the alcohol podophyllotoxin with excess chlorosulfonic acid affording a highly reactive O-sulfonyl chloride intermediates that are immediately subjected to sulfonamidation reactions with ammonia or amino/heteroaryl derivatives. The obtained compounds were identified by IR and ${ }^{1} \mathrm{H}$ and ${ }^{13} \mathrm{C}-\mathrm{NMR}$ spectral data. The prepared compounds were evaluated for their cytotoxic activity against MCF7, A2780, and HT29, in addition to MRC5. All tested compounds showed cytotoxicity in the micromolar range but were less potent than podophyllotoxin, which was used as a reference. Compound 3 was the most potent derivative, and it exhibited a good selectivity margin; in fact, it showed 9.1-13.5 times more cytotoxicity in cancer cells compared to normal MRC5 cells. Compounds 2 and 7 showed cytotoxicity with moderate selectivity. Consequently, compounds 2,3 , and 7 were also evaluated for their apoptotic inducing ability on MCF7 cells and showed activity in a dose-dependent manner that partially explains the mechanism of their activity. These results indicate that podophyllotoxin sulfamate derivatives are valid candidates for further development as anticancer agents.

\section{Conclusion}

Derivatives of 4-O-podophyllotoxin sulfamate were synthesized through a simple and direct one-pot methodology developed in our laboratory. The synthesized derivatives showed cytotoxicity in the micromolar concentrations. Compounds $(2,3$, and 7$)$ showed a dose dependent increase in apoptotic events. Yet, the activity of all compounds was inferior to that of podophyllotoxin. We are looking for optimizing the core structure of this scaffold and exploring the activity of these derivatives in vivo study to get insights about the efficacy and tolerability in animal models.

\section{Data Availability}

Data used to support the findings of this study are available from the corresponding author upon request.

\section{Conflicts of Interest}

The authors declare that they have no conflicts of interest pertaining to the publication of this paper.

\section{Acknowledgments}

This project was funded by the National Plan for Science, Technology, and Innovation (MAARIFAH), King Abdulaziz City for Science and Technology, Kingdom of Saudi Arabia (award number 12-MED2310-10), through Science and Technology Unit (STU) at Umm Al-Qura University.

\section{Supplementary Materials}

${ }^{1} \mathrm{H}-\mathrm{NMR}$ spectrum $\left(500 \mathrm{MHz}, \mathrm{CDCl}_{3}\right.$ ) of podophyllotoxin and its derivatives: $2-7$. Page 2: ${ }^{1} \mathrm{H}-\mathrm{NMR}$ of compound 1: podophyllotoxin. Page 3: ${ }^{1} \mathrm{H}-\mathrm{NMR}$ of compound 2: 4-O-podophyllotoxin sulfamate. Page $4:{ }^{1} \mathrm{H}-\mathrm{NMR}$ of compound 3: 4-N(2-pyridinylmethyl)-podophyllotoxin sulfamate. Page $5:{ }^{1} \mathrm{H}$ NMR of compound 4: 4-N-(2-pyridinylethyl)-podophyllotoxin sulfamate. Page $6:{ }^{1} \mathrm{H}-\mathrm{NMR}$ of compound 5: 4- $\mathrm{N}$-(2-pyridinyl)podophyllotoxin sulfamate. Page 7: ${ }^{1} \mathrm{H}-\mathrm{NMR}$ of compound 6: 4-N-(4-flourophenyl)-podophyllotoxin sulfamate. Page $8:{ }^{1} \mathrm{H}$ NMR of compound 7: 4-N-(2-anthracenyl)-podophyllotoxin sulfamate. (Supplementary Materials)

\section{References}

[1] D. E. Jackson and P. M. Dewick, "Aryltetralin lignans from Podophyllum hexandrum and Podophyllum peltatum," Phytochemistry, vol. 23, no. 5, pp. 1147-1152, 1984. 
[2] R. M. Moraes, E. Bedir, C. Burandt, C. Canel, and I. A. Khan, "Evaluation of Podophyllum peltatum accessions for podophyllotoxin production," Planta Medica, vol. 68, no. 4, pp. 341-344, 2002.

[3] M. Jordan and K. Kamath, "How do microtubule-targeted drugs work? An overview," Current Cancer Drug Targets, vol. 7, no. 8, pp. 730-742, 2007.

[4] J. D. Loike, C. F. Brewer, H. Sternlicht, W. J Gensler, and S. B Horwitz, "Structure-activity study of the inhibition of microtubule assembly in vitro by podophyllotoxin and its congeners," Cancer Research, vol. 38, no. 9, pp. 2688-2693, 1978.

[5] W.-F. Kao, D.-Z. Hung, W.-J. Tsai, K.-P. Lin, and J.-F. Deng, "Podophyllotoxin intoxication: toxic effect of Bajiaolian in herbal therapeutics," Human and Experimental Toxicology, vol. 11, no. 6, pp. 480-487, 1992.

[6] B. Meyer, N. Ferrigni, J. Putnam, L. Jacobsen, D. Nichols, and J. McLaughlin, "Brine shrimp: a convenient general bioassay for active plant constituents," Planta Medica, vol. 45, no. 5, pp. 31-34, 1982.

[7] L. L. Hu, X. Zhou, H. L. Zhang et al., "Exposure to podophyllotoxin inhibits oocyte meiosis by disturbing meiotic spindle formation," Scientific Reports, vol. 8, pp. 1-8, 2018.

[8] Y. Yang, J. Bteich, and S.-D. Li, "Current update of a carboxymethylcellulose-PEG conjugate platform for delivery of insoluble cytotoxic agents to tumors," The AAPS Journal, vol. 19, no. 2, pp. 386-396, 017.

[9] Y.-Q. Liu, J. Tian, K. Qian et al., "Recent progress on C-4Modified podophyllotoxin analogs as potent antitumor agents," Medicinal Research Reviews, vol. 35, no. 1, pp. 1-62, 2015.

[10] Z.-Z. Wang, W.-X. Sun, X. Wang et al., "Design, synthesis, biological evaluation, and 3D-QSAR analysis of podophyllotoxin-dioxazole combination as tubulin targeting anticancer agents," Chemical Biology and Drug Design, vol. 90, no. 2, pp. 236-243, 2017.

[11] X. Zhang, K. P. Rakesh, C. S. Shantharam et al., "Podophyllotoxin derivatives as an excellent anticancer aspirant for future chemotherapy: a key current imminent needs," Bioorganic and Medicinal Chemistry, vol. 26, no. 2, pp. 340-355, 2018.

[12] M. Bkhaitan, S. K. Bardaweel, G. Abushaikha, A. Z. Mirza, and K. A. Sweidan, "Synthesis and antiproliferative activity of $4 \beta$ $\mathrm{O}$-substituted, $4 \beta-\mathrm{N}$-substituted deoxypodophyllotoxin derivatives, and $4 \beta-\mathrm{O}$ H- 4'- O -substituted podophyllotoxin," ChemistrySelect, vol. 5, no. 47, pp. 14924-14929, 2020.

[13] L. Zhang, F. Chen, J. Wang et al., "Novel isatin derivatives of podophyllotoxin: synthesis and cytotoxic evaluation against human leukaemia cancer cells as potent anti-MDR agents," RSC Advances, vol. 5, no. 118, pp. 97816-97823, 2015.

[14] M. M. Bkhaitan, A. Z. Mirza, H. Shamshad et al., "Identification of potent virtual leads and ADME prediction of isoxazolidine podophyllotoxin derivatives as topoisomerase II and tubulin inhibitors," Journal of Molecular Graphics and Modelling, vol. 73, pp. 74-93, 2017.

[15] R. Ali., P. Hilgard, S. Florentine et al., "Current development of podophyllotoxins," Cancer Chemotherapy and Pharmacology, vol. 7, pp. 93-98, 1982.

[16] E. Baldwin and N. Osheroff, "Etoposide, topoisomerase II and cancer," Current Medicinal Chemistry-Anti-Cancer Agents, vol. 5, no. 4, pp. 363-372, 2005.

[17] T. F. Imbert, "Discovery of podophyllotoxins," Biochimie, vol. 80, no. 3, pp. 207-222, 1998.
[18] M. Guerram, Z.-Z. Jiang, and L.-Y. Zhang, "Podophyllotoxin, a medicinal agent of plant origin: past, present and future," Chinese Journal of Natural Medicines, vol. 10, no. 3, pp. 161-169, 2012.

[19] X.-H. Xu, X.-W. Guan, S.-L. Feng, Y.-Z. Ma, S.-W. Chen, and L. Hui, "One-pot synthesis and biological evaluation of $\mathrm{N}$ -(aminosulfonyl)-4-podophyllotoxin carbamates as potential anticancer agents," Bioorganic \& Medicinal Chemistry Letters, vol. 27, no. 13, pp. 2890-2894, 2017.

[20] A. Kamal, B. Ashwini Kumar, M. Arifuddin, and S. G. Dastidar, "Synthesis of $4 \beta$-amido and $4 \beta$-sulphonamido analogues of podophyllotoxin as potential antitumour agents," Bioorganic and Medicinal Chemistry, vol. 11, no. 23, pp. 5135-5142, 2003.

[21] S.-J. Zhu, H.-Z. Ying, Y. Wu et al., "Design, synthesis and biological evaluation of novel podophyllotoxin derivatives bearing $4 \beta$-disulfide/trisulfide bond as cytotoxic agents," RSC Advances, vol. 5, no. 125, pp. 103172-103183, 2015.

[22] A. N. Abdalla, U. Shaheen, Q. M. A. Abdallah et al., "Proapoptotic activity of Achillea membranacea essential oil and its major constituent 1,8-cineole against A2780 ovarian cancer cells," Molecules, vol. 25, no. 7, p. 1582, 2020.

[23] A. Bader, Q. M. A. Abdallah, M. I. S. Abdelhady et al., "Cytotoxicity of some plants of the asteraceae Family: antiproliferative activity of psiadia punctulata root sesquiterpenes," Records of Natural Products, vol. 13, pp. 307-315, 2018.

[24] M. M. Bkhaitan, M. Alarjah, A. Z. Mirza, A. N. Abdalla, H. M. El-Said, and H. S. Faidah, "Preparation and biological evaluation of metronidazole derivatives with monoterpenes and eugenol," Chemical Biology and Drug Design, vol. 92, no. 6, pp. 1954-1962, 2018.

[25] U. Shaheen, E. A. Ragab, A. N. Abdalla, and A. Bader, "Triterpenoidal saponins from the fruits of Gleditsia caspica with proapoptotic properties," Phytochemistry, vol. 145, pp. $168-178,2018$. 